\title{
Redefinition of Mesoleptobasis Sjöstedt 1918 with the inclusion of Metaleptobasis cyanolineata (Wasscher 1998) comb. nov. and description of a new species, Mesoleptobasis elongata (Odonata: Coenagrionidae)
}

\author{
ROSSER W. GARRISON ${ }^{1} \&$ NATALIA VON ELLENRIEDER ${ }^{2}$ \\ ${ }^{\text {I}}$ Plant Pest Diagnostic Branch, California Department of Food and Agriculture, Sacramento, United States of America. \\ E-mail: rgarrison@cdfa.ca.gov \\ ${ }^{2}$ Instituto de Bio y Geociencias, Museo de Ciencias Naturales de Salta, Universidad Nacional de Salta, Salta, Argentina. \\ E-mail: natalia.ellenrieder@gmail.com
}

\begin{abstract}
Metaleptobasis cyanolineata is transferred to Mesoleptobasis and a new species, Mesoleptobasis elongata, is described. The genus is diagnosed by the combination of rounded frons, highly modified pronotum with long processes at least in males, pterothoracic color pattern lacking dark mid-dorsal stripe, pretarsus with supplementary tooth vestigial or absent, vein descending from quadrangle forming an unbroken line to wing margin, and genital ligula with a small inner fold and with spine-like projections on lateral margins distal to flexure. Its species are illustrated, mapped, and keyed.
\end{abstract}

Key words: Odonata, damselfly, Coenagrionidae, key, Mesoleptobasis, Metaleptobasis, taxonomy, South America

\section{Resumen}

Metaleptobasis cyanolineata es transferida a Mesoleptobasis y una nueva especie, Mesoleptobasis elongata, es descripta. El género es diagnosticado por la combinación de frente redondeada, pronoto marcadamente modificado con largos procesos al menos en machos, patrón de coloración pterotorácico sin raya medio-dorsal oscura, pretarso con diente suplementario vestigial o ausente, vena descendente del cuadrángulo formando una línea recta hasta el margen del ala, y lígula genital con un pequeño pliegue interno y con proyecciones a modo de espinas en los margenes laterales distalmente a la flexura. Se proveen ilustraciones, mapa y clave para sus especies.

\section{Introduction}

Mesoleptobasis Sjöstedt 1918 is a small, poorly known South American genus of medium-sized pale damselflies. Sjöstedt (1918) described it to include his new species M. incus. He distinguished it from Leptobasis Selys 1877 by 1) CuP located midway between first and second antenodals rather than closer to second antenodal; 2) short $\mathrm{CuA}$ ending at vein descending from nodus or one to three cells distal to it; 3 ) pterostigma covering less than one cell; 4) upright process on posterior margin of male prothorax; 5) male cerci very short and wide, triangular, shorter than S10; and 6) long, narrow male paraprocts convergent distally. Santos (1961) described two new species of Mesoleptobasis and distinguished them from M. incus. Other than mere mention in synonymic and distributional lists, the genus was not treated again until Lencioni (2006) reproduced drawings of the three species from original descriptions and provided a brief diagnosis based on the species from Brazil only. Heckman (2008) keyed the genus and its species, but his work relied entirely on other sources and repeated errors in the literature. 